\title{
Imiquimod 5\% Cream in Topical Treatment of Facial Basal Cell Carcinoma
}

\author{
Svetlana D. Grubor ${ }^{1}$, Vesna J. Tatljak-Vlahovic ${ }^{2}$, Biljana P. Radojevic ${ }^{3}$ \\ ${ }^{1}$ Department of Dermatovenerology Clinical Hospital Center Zemun, Belgrade, Serbia \\ ${ }^{2}$ City Department of Dermatovenerology, Belgrade, Serbia \\ ${ }^{3}$ Department of Clinical Pharmacology Clinical Hospital Center Zemun, Belgrade, Serbia
}

\section{SUMMARY}

Introduction: Basal Cell Carcinoma (BCC) is a non-melanocytic skin neoplasm originating from the cells in the basal epidermal layer, hair follicle shell or other skin adnexa. It is the most frequent skin malignancy. Treatment is surgical or nonsurgical. Cases reports: Herein we present 2 patients with superficial type of BCC and actinic keratosis of the face. The patients have been diagnosed by dermoscopy DermLite dermatoscope by $3 \mathrm{Gen}$ Inc. manufacturer, and skin biopsy has been performed for histopathological examination. The superficial BCC of the face has been treated with $5 \%$ Imiquimod cream once a day for 5 days in a week, during 4 weeks, with erosions and crusts until complete skin restoration.

Conclusion: Based on these case reports, it could be concluded that $5 \%$ Imiquimod cream is safe and effective treatment for superficial BCC and represents an optimal treatment to achieve good clinical and esthetic effect for the patients.

Keywords: Basal Cell Carcinoma, actinic keratosis, Imiquimod, toll-like receptor

\section{INTRODUCTION}

Basal cell carcinoma (BCC) is a non-melanocytic skin tumor originating from the cells in the basal epidermal layer, hair follicle shell or other skin adnexa. It is the most frequent skin malignancy in Caucasian population, with skin phototype 1 and 2 [1]. It appears after the age of 60 years, rarely in younger people, sometimes more in men because of the professional occupation with sun exposure [2].

Typical localization could be in photo exposed skin, such as the face, head /neck or the trunk, but mainly on the nose or cheek, usually with actinic keratosis that could evolve into squamous cell carcinoma (SCC). Clinical presentation may be different, like superficial or nodular type, rarely ulcerating, or sometimes pigmented, resembling melanocytic lesions $[3,4]$

The tumor can be diagnosed by dermatoscopy and verified by histopathological examination of the excised tissue [5].

The treatment is:

a) Surgical excision is the first choice therapy in case of the large tumor, sometimes with plastic surgery technique [6];

b) Nonsurgical:

1) Imiquimod $5 \%$ cream as immunomodulator, targeting toll like receptors (TLR) 7, stimulates skins own immunity. This agonist TLR 7 induces increased production of interferonalpha, interleukin-12, tumor necrosis factoralpha and a Th1 prone immune response. Also, 
it induces release of calcium from the internal store in cells, independently of TLR7 pathway, and causes pruritogenic effect. It is used for superficial tumors of the face $[7,8,9,10]$;

2) 5-fluorouracil topical cream with cytotoxic effect, that inhibits DNA synthesis by blocking conversion of deoxyuridylic acid to thymidylic acid by the cellular enzyme thymidylate synthase. This method is used for superficial lesions of the trunk / extremities [11];

3) Photodynamic therapy (PTD) uses specific light waves to photoexcited molecules in neoplastic cells. 5 -aminolevulinic acid is photo reactive molecule for PTD, and it is activated by blue light [12];

4) Systemic retinoids could be found in the literature as a method of treating BCC, but their use is very rare because of many side effects [13];

5) Radiotherapy used to be the first choice treatment for $\mathrm{BCC}$ in the past. It takes a long time for procedure that is expensive and toxic, but could be recommended for the elderly patients with low-dose radiation [14];

6) Cryotherapy as a cheap and easy to access therapy has limited usage in small number of patients for treating BCC with undesirable effect of tumor growth if it is not removed (completely)[15].

\section{THE AIM}

The aim of this paper is to show possibilities and results of non- surgical topical treatment of superficial BCC by Imiquimod 5\% cream.

\section{CASES REPORTS}

Patients with manifested tumors of the photo exposed skin have been clinically examined in the Department of Dermatovenerology, Clinical Hospital Center, Zemun and City Department of Dermatovenerology:

1. Case of an elderly patient with superficial tumor of the face. A male patient, 72 years old has been clinically examined and tumor of the forehead was found. The tumor was $7 \times 4 \mathrm{~mm}$ in diameter, sometimes with shallow erosion and tiny crust, growing slowly for several months. Two similar tumors located around nose and mouth have been excised 7 and 4 years ago and histopathologically verified as BCC.

2. Case of a superficial tumor of the face in a female patient 53 years and skin phototype 1 , with positive family history of epithelial tumors. Tumefaction of the left cheek, $6 \mathrm{~mm}$ in diameter, was found by clinical examination. The tumor was growing slowly for the last 6 months, with occasional bleeding and crusting. Also, several actinic keratosis has been observed in photo exposed skin on the nose and cheek.

Each patient has had dermatoscopy performed by DermLite dermatoscope and partial skin biopsy of the tumor and surrounding skin for histopathological diagnosis. Dermatoscopy (Fig 1 and 2), showed tumors as a non- pigmented lesion, with arborized blood vessels, structure less areas.
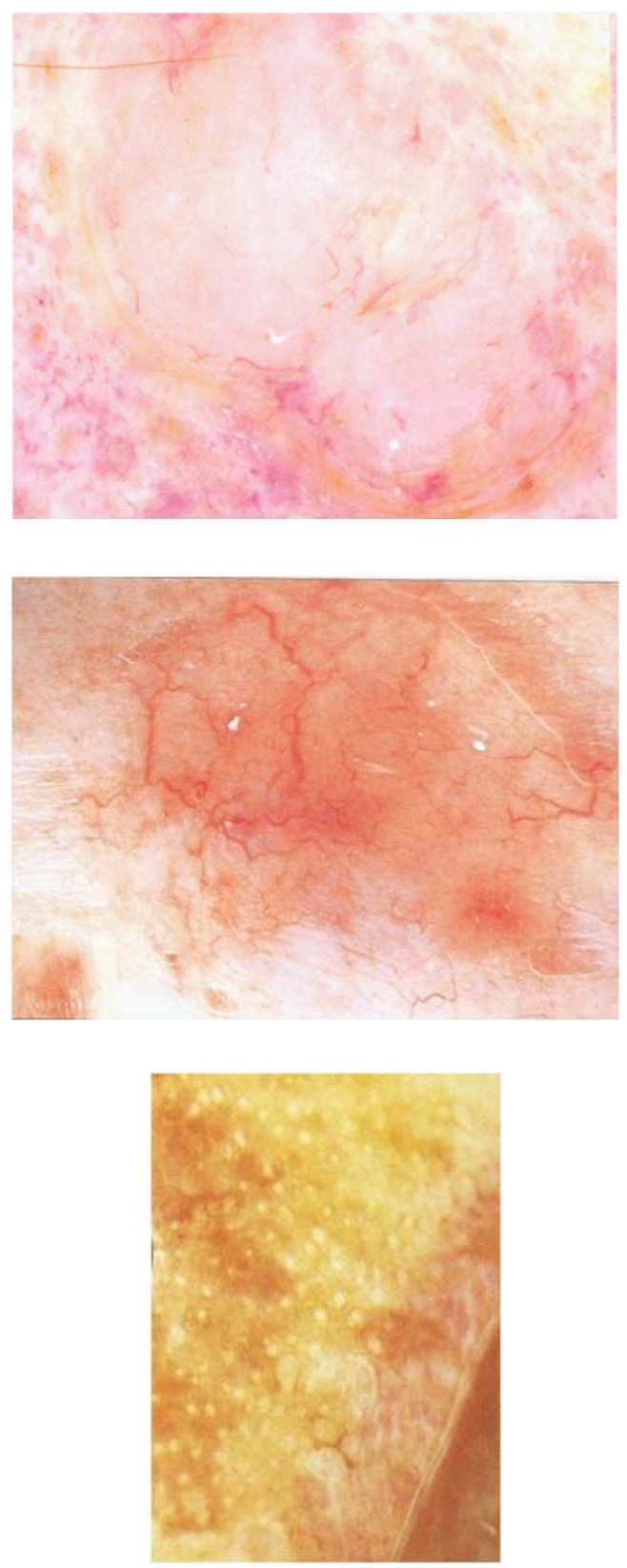

Fig 1. Dermatoscopy findings of $B C C$ in case 1

Fig 2. Dermatoscopy findings of $\mathrm{BCC}$ in case 2

Fig 3. Dermatoscopy findings of actinic keratosis in case 2 
Fig 4. Case 1 - the skin condition in $4^{\text {th }}$ week

Fig 5. Case 1- without recidivant tumor after 6 months

Fig 6. Case 2 - the skin condition in $4^{\text {th }}$ week

Fig 7. Case 2 - after 3 months without recidivant tumors and actinic keratosis

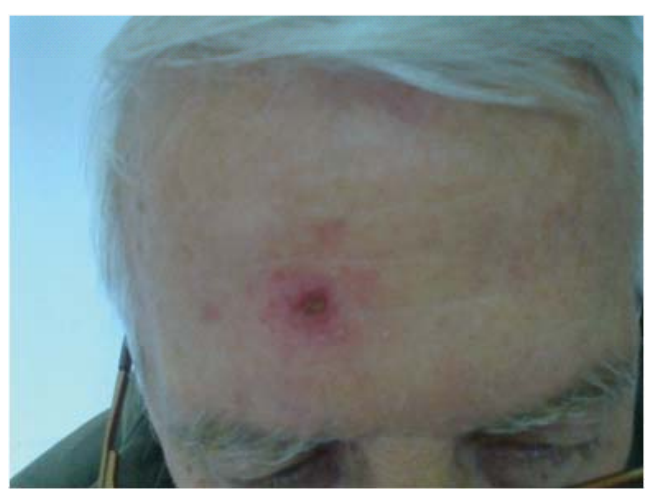

Dermatoscopy of the actinic keratosis (Fig 3) showed uniform symmetric distribution of light brown color around follicular openings.

Histopathological examinations diagnosed tumors as superficial BCC with immature basal cells protruding towards dermis.

The superficial BCC of the face together with actinic keratosis has been treated with $5 \%$ Imiquimod cream once a day for 5 days in a week, during 4 weeks, (fig 4, fig 6) until complete restoration of epithelial layer instead of tumor (fig 5- 6 months after the therapy; fig 7- 3 months after the therapy without recidivant tumors). The patients have had local skin irritation such as redness, edema, erosion with crust and itching sometimes.

\section{DISCUSSION}

It is necessary to monitor the skin condition of those patients once diagnosed with BCC by regular clinical and dermatoscopy examinations in the following years. The prevention of new BCC is conducted from April to October every year by using sun protection factors (SPF) creams on the photo exposed skin, together with mechanical protection by clothing, ultraviolet filtered sunglasses. Sunbathing is absolutely forbidden in the interval from 11 am till 15 pm [2].Which method of tumor therapy should we choose depends on the age and general condition of the patient, the diameter, localization and type of the tumor, also. The aim of the treatment is good esthetic effect that could be obtained by optimal cooperation with the patient [3]. Those patients treated by topical Imiquimod 5\% cream have experienced local skin reactions on the application site, and that are the most common adverse reactions that corresponded positively with the immune response [16]. They should be advised to carry out thorough hygiene measures before and after cream applying.

The advantages of this topical treatment are many: affordable cost of the therapy that is conducted in domestic environment at home, the possibilities of removal of both manifested and invisible actinic keratosis. 


\section{CONCLUSION}

Our findings support the results of clinical trials that showed the Imiquimod as a safe and effective treatment option of superficial BCC, which might be able to prevent the disease progression to the squamous cell carcinoma $[10,11,17,18]$.

\section{REFERENCES}

1. Lien MH, Sondak VK. Nonsurgical treatment options for Basal cell carcinoma. J Skin cancer 2011; 2011:571734.Epub 2011 Jan 9.

2. Fitzpatrick JE, Morelli JG. Dermatology secrets plus. Elsevier Mosby Philadelphia 2011.pp 352-57

3. Karadaglic Dj. Dermatologija. Vojnoizdavacki zavod Beograd 2000. pp 825-33

4. Dodds A, Chia A, Shumack S. Actinic keratosis: rationale and management. Dermatol Ther (Heidelb). 2014 Jun; 4(1):11-31. doi: 10.1007/s13555-0140049-y. Epub 2014 Mar 14.

5. Menesi W, Buchel EW, Hayakawa TJ. A reliable frozen section technique for basal cell carcinomas of the head and neck. Can J Plast Surg. 2014 Fall; 22(3):179- 82.

6. Johr R, Soyer PH, Argenziano G, Hofman-Wellenhof $R$, Scalvenzi M. Dermoscopy the essentials. Elsevier Saunders 2012.

7. Novak N, Yu CF, Bieber T, Allam JP. Toll like receptor 7 agonists and skin. Drug News Perspect.2008 Apr; 21(3):158-65

8. Hwang H, Min H, Kim D, Yu SW, Jung SJ et al. Imiquimod induces a Toll-like receptor 7 -independent increase in intracellular calcium via IP (3) receptor activation. Biochem Biophys Res Commun. $2014 \mathrm{Jul}$ 18; 450(1):875-9. doi: 10.1016/j.bbrc.2014.06.084. Epub 2014 Jun 24.

9. Tillman DK Jr, Caroll MT. Topical imiquimod therapy for basal and squamous cell carcinomas: a clinical experience. Cutis 2007 Mar; 79(3):241-8.

10. Sligh JE jr. New therapeutic options for actinic keratosis and basal cell carcinoma. Semin Cutan Med Surg. 2014 Jun; 33(4 Suppl):S76-80. doi: 10.12788/j.sder.0100.

11. Love WE,Bernhard JD,Bordeaux JS. Topical imiquimod or fluorouracil therapy for basal and squamous cell carcinoma: a systematic review. Arch Dermatol 2009 Dec; 145(12):1431-8

12. Arits AH, Mosterd K, Essers BA, Spoorenberg E, Sommer A, De Rooij MJ, et al. Photodynamic therapy versus topical imiquimod versus topical fluorouracil for treatment of superficial basal cell carcinoma; a single blind, non-inferiority, randomised controlled trial. Lancet Oncol. 2013 Jun;14(7):647-54. Epub 2013 May 15.

13. Bettoli V, Zauli S, Virgili A. Retinoids in the chemoprevention of non-melanoma skin cancers: why, when and how. J Dermatolog Treat. 2013 Jun; 24(3):235-7. doi: 10.3109/09546634.2012.746634. Epub 2013 Feb 3.

14. Olschewski T, Bajor K, Lang B, Lang E, Seengeschmeidt MH. Radiotherapy of basal cell carcinoma of the face and head: Importance of low dose per fraction on long-term outcome. J Dtsch Dermatol Ges. 2006 Feb; 4(2):124-30.

15. Chiriac A, Mihaila D, Foia L, Solovan C. Basal cell carcinomas in elderly patients treated by cryotherapy. Clin Interv Aging. 2013; 8:341-4.doi: 10.2147/ CIA.S42174. Epub 2013 Mar 26.

16. Oldfield V, Keating GM, Perry CM. Imiquimod: in superficial basal cell carcinoma. Am J Clin Dermatol. 2005; 6(3):195-200; discussion 201-2.

17. Geisse J, Caro I, Lindholm J, Golitz L, Stampone $P$, Owens M. Imiquimod 5\% cream for the treatment of superficial basal cell carcinoma: results from two phase III,randomised, vehicle-controlled studies. J Am Acad Dermatol. 2004 May; 50(5):722-33.

18. Kopera D, Kerl H. Visualisation and treatment of subclinical actinic keratosis with topical imiquimod 5\% cream: an observational study. Biomed Res Int. 2014; 2014:135916. doi: 10.1155/2014/135916. Epub 2014 May 11. 


\section{Primena imiquimod 5\% krema u topikalnom lečenju basocelularnih karcinoma kože lica}

Svetlana D. Grubor ${ }^{1}$, Vesna J. Tatljak-Vlahović ${ }^{2}$ Biljana P. Radojević ${ }^{3}$

${ }^{1}$ Kabinet za dermatovenerologiju, Kliničko-bolnički centar Zemun, Beograd, Srbija

${ }^{2}$ Gradski Zavod za dermatovenerologiju, Beograd, Srbija

${ }^{3}$ Služba za kliničku farmakologiju, Kliničko-bolnički centar Zemun, Beograd, Srbija

\section{KRATAK SADRŽAJ}

Uvod: bazocelularni karcinom (BCC) je nemelanotični tumor kože, koji potiče iz ćelija bazalnog sloja, folikula dlake ili drugih adneksa kože. To je najčešći maligni tumor kože a leči se hirurškim ili nehirurškim putem.

Prikazi slučajeva: predstavljamo 2 pacijenta sa supeficijalnim tipom BCC -a i aktiničnim keratozama lica. Dijagnoza je postavljena dermoskopski, pomoću DermLite dermoskopa (proizvodjač 3Gen Inc.), kao i biopsijom i histopatološkim pregledom. Površni BCC kože lica tretirani su Imiquimod 5\% kremom jednom dnevno , 5 dana tokom 4 nedelje, sa pojavom erozija i krasta, do potpunog zarastanja kože.

Zaključak: Na osnovu ovih prikaza slučajeva, može se zaključiti da je Imiquimod $5 \%$ krem(a) siguran i efikasan metod lečenja površnih BCC, kao i da je ovo optimalan metod lečenja kojim se postiže dobar klinički i estetski efekat.

Ključne reči: bazocelularni karcinom, aktinična keratoza, Imiquimod, toll-like receptor 